\title{
Cezaevlerindeki İntihar Davranışlarında Bir Risk Faktörü Olarak Madde ve Alkol Bağımlılı̆̆ı*
}

\author{
Substance and Alcohol Addiction as A Risk Factor in Suicide Behavior in Prisons
}

\author{
Mehmet Murat AKIN ${ }^{\mathrm{a}}$ \\ ${ }^{a}$ Dr. Bitlis E Tipi Kapalı Ceza İnfaz \\ Kurumu, Bitlis, Türkiye, \\ mehmet.murat.akinn@gmail.com, \\ ORCID; 0000-0001-5728-7047
}

\begin{abstract}
ÖZ
Amaç: $\mathrm{Bu}$ çalışmada, madde ve alkol bağımlılı̆̆ı olan hükümlü ve tutukluların, cezaevinde yaşadıkları yoksunluk sendromunun intihar davranışı açısından oluşturduğu risk faktörünün belirlenmesi amaçlanmıştır. Yöntem: Tanımlayıcı tipteki bu çalışma, 2015 yılında 18 ayrı cezaevinde intihar girişiminde bulunan 102 hükümlü ve tutuklu ile yürütülmüştür. İhtiyaç duyulan veriler, araştırmacı tarafından hazırlanan ve uygulanan, hükümlü ve tutukluların intihar girişimi öncesi ve sonrasına yönelik düşünceleri ile bu kişilere ait sosyo-demografik bilgileri içeren anket formu ile toplanmıştır. Bulgular: İntihar girişiminde "madde ve alkol yoksunluğunun" etkili olduğu kişilerin oranı \% 3,9 oranındadır. Sonuç: Madde ve alkol bağımlılığı olan hükümlü ve tutukluların, yoksunluk sürecinde daha fazla psiko-sosyal desteğe ihtiyacı olduğu görülmektedir. Özellikle yoksunluğun ilk döneminde, bireysel ve grup terapileri ile desteklenmesi, gerekmesi durumunda ise ilaç desteği almalarının, bu kişilerin intihar davranışından korumada yararlı olacağı düşünülmektedir
\end{abstract}

Anahtar Kelimeler: Bağımlılık, Yoksunluk, İntihar, Cezaevi, Hükümlü ve Tutuklu

\begin{abstract}
Objective: In this study, it was aimed to determine the risk factor of deprivation syndrome experienced in prison by convicts and prisoners with substance and alcohol addiction in terms of suicidal behavior.Method: This descriptive study was conducted with 102 convicts and detainees who attempted suicide in 18 different prisons in 2015. The required data were collected with a questionnaire prepared and applied by the researcher, which includes the opinions of convicts and detainees before and after suicide attempts and socio-demographic information of these people.Results: The proportion of people who are affected by "drug and alcohol deprivation" in suicide attempt is 3.9\%.Conclusion: Convicts and detainees with substance and alcohol addiction need more psycho-social support during the deprivation process. Especially in the first period of deprivation, individual and group therapies and, if necessary, taking medication will be beneficial in protecting these people from suicidal behavior..
\end{abstract}

Keywords: Addiction, Deprivation, Suicide, Prison, Convict and Detainee.

\section{GİRIŞ}

Dünya'da farklı yerlerde yapılan araştırmalar, cezaevlerinde en yaygın ölüm nedenlerinin başında intihar sonucu ölümlerin geldiğini ve oransal açıdan genel nüfusun çok üzerinde olduğunu ortaya koymaktadır(Duthe vd.,2014: 468; Fazel vd., 2011:194; Konrad vd.,2007:118;Fruehwald vd.,2000:364;Haycock,1989:89;Hayes,1995;Matschnig vd.,2006:8;Stuart,2003:562). Cezaevlerindeki intihar davranışlarına nedensellik yönü ile bakıldığında ise izolasyon, belirsizlik, psikolojik rahatsızlıklar, sevdiklerinden ayrılma, alışkanlıklarından vazgeçme, ilişki sorunları, madde bağımlılığı gibi birçok risk faktörü öne çıkmaktadır (Clements-Nolle vd.,2009:189;Dear,2006;Dye vd.,2013:844;Fazel vd.,2008:1728;Grossmann,1992:410;Krames\&

\footnotetext{
* Bu makalede bilimsel araştırma ve yayın etiği ilkelerine uyulmuştur. / In this article, the principles of scientific research and publication ethics were followed.

Bu makalede kullanılan anket Adalet Bakanlı̆̆ı'nın 12.10.2015 tarih ve E.1617/153037 sayılı izni ile gerçekleştirilmiştir. / The Ministry of Justice has given permission to the survey used in this study with the letter dated 12.10.2015 and numbered E.1617 / 153037 .
} 
Flett,2005:18; Liebling,1999:289; Marzano vd.,2011:82;Palmer\& Connelly,2005:166;Sykes,1958;Towl vd.,2001). Konuyu Türkiye cezaevlerinde ve genel nüfusunda intihar sonucu gerçekleşen ölümleri karşılaştırarak ele aldığımızda, dünyadaki diğer araştırmalarla benzer bulgulara ulaşmaktayız. Türkiye İstatistik Kurumu'nun 2014 yılı verilerine göre 100.000'de 4,19 olan genel nüfusa ait kaba intihar hızı (TÜİK,2015), Ceza ve Tevkifevleri Genel Müdürlüğünün 2014 yılı verilerinde 100.000 'de 28 gibi bir oranda çıkmaktadır ki (CTE,2014), arada neredeyse 7 kat bir fazlalık söz konusudur. Yine Türkiye İstatistik Kurumu'na göre intiharlar, Türkiye'deki ölümlerin \%1'inin sebebi iken (TÜİK;2015), cezaevlerindeki ölümlerin \%15'inin sebebini intiharlar oluşturmaktadır. Ceza Tevkifevleri Genel Müdürlüğüne ait aynı kaynakta yer alan başka verilerden, yaşlılık ve hastalık gibi doğal ölümlerden sonra cezaevlerinde ikinci büyük ölüm nedeninin intiharlar olduğu sonucunu çıkarmaktayız (CTE,2014).

Ceza infaz kurumlarında intihar davranışının nedenlerinden biri olarak araştırmamıza konu edindiğimiz madde ve alkol kullanımına bağlı yoksunluk, dünya cezaevlerinde intihar davranışının önemli sebeplerindendir(Fazel vd.,2017:1730;Goss vd.,2002:577). Madde ve alkol kullanımından kaynaklı yoksunluğun, Türkiye'deki bazı cezaevlerinde intihar davranışlarının sebepleri arasında olup olmadığı, varsa bunun etkisini ortaya koyabilmek adına gerçekleştirilen bu çalışmada, öncelikle yoksunluğun kavram olarak anlamını ortaya koyarak başlamak doğru olacaktır. Yoksunluk "Çok fazla ve uzun süreli alkol/madde kullanımından sonra bunun azaltılmasına ya da bırakılmasına băglı olarak ortaya çıkan bir sendrom” şeklinde tanımlanmaktadır (Ögel vd., 1998). Hayes’in yaptığı bir araştırma da belirttiği (1989), genel itibari ile kişilerin cezaevlerine girdiklerinde kendilerini belirsizlik içinde ve güvensiz bir ortamda hissetmesi, özellikle madde ve alkol bağımlısı olan kişilerin yoksunluğa bağlı olarak bu süreci daha yoğun yaşamaları, depresyon ve kaygıdan kaynaklı olarak intihar girişimine yönelmeleri nedeni ile, bu kişiler cezaevlerinde genel nüfusa oranla daha fazla intihar davranışı gerçekleşmektedir(Hayes,1989:12). Neden olabileceği olası problemlerde göz önünde bulundurularak Türkiye cezaevlerinde alkol kullanımı ile ilgili çeşitli önlemler alınmaya çalışılmaktadır. Bu kapsamda hükümlü ve tutukluların, kalmış oldukları oda ve eklentilerinde neleri bulundurabilecekleri ve bulunduramayacakları yasa ile açıklanmıştır. En belirgin yasaklardan biri de, uyarıcı maddeler ile alkole dair yasaklardır. Bu tür ürünlerin kuruma girişi ağır müeyyidelerle kontrol altına alınmaya çalışılmıştır ( Mevzuatı Geliştirme ve Yayın Genel Müdürlüğ̈̈;2006:8344). Dolayısı ile yoksunluk sendromu, cezaevlerinde bulunan bağımlı bir kişinin alkol ve madde kullanımını zorunlu olarak terk etmesi nedeni ile daha yoğun yaşanabilmektedir.

Araştırmamızın temel amacı da, bu durumdan hareketle, Türkiye'deki bazı cezaevlerindeki madde ve alkol bağımlısı hükümlü ve tutukluların intihar davranışında bulunmalarında, yoksunluğun etkisini değerlendirmek ve bazı öneriler sunmaktır. Konu ile ilgili Türkiye'deki literatür incelendiğinde ise üst mercilerden izin alma prosedürünün zorluğu, konunun hassasiyeti, kuruma giriş ve çıkışlarda yaşanan sıkıntıların olması gibi gerekçelerden kaynaklı olduğu düşünülen sebeplerle, yeterli çalışma bulmakta sıkıntı çekilmektedir. Bu nedenle araştırmanın gerek literatüre sağlayacağı katkı, gerekse saha çalışanlarına rehberlik etmesi yönü ile önem taşıdığı düşünülmektedir.

\section{YÖNTEM}

Araştırmanın evreni, Türkiye' deki cezaevlerinde bulunan ve intihar girişiminde bulunmuş bireylerdir. Araştırmanın örneklemi için, 18 ayrı cezaevinde kalan intihar girişiminde bulunmuş 102 hükümlü ve tutuklu ile yüz yüze görüşmeler gerçekleştirilmiş ve veriler anket yöntemi ile elde edilmiştir. Örneklem grubunun seçimi sürecinde, cezaevlerinde intihar ve kendine zarar verme davranışları ile ilgili gerçekleşen olayların vukuat olarak bilgilendirme yapıldığı Adalet Bakanlığı Ceza ve Tevkifevleri Genel Müdürlüğü Asayiş Şube Müdürlüğü ve ilgisine göre Eğitim Daire Başkanlığı Yetişkin İyileştirme Şube Müdürlüğüne gelen veriler, alınan izin doğrultusunda taranmış, kendine zarar verme ve intihar girişimi davranışları ayrıştırılarak örneklem grup belirlenmiştir. Bu ayrıştırmanın ardından intihar girişiminde bulunan hükümlü ve tutukluların mevcut bulunduğu kurumlar tespit edilmiştir. İntihar girişimi ve kendine zarar verme davranışının ayrıştırılmasında raporlamaların yanı sıra, girişimin gerçekleştiği kurumların psiko-sosyal servislerinde görev yapan psikolog ve sosyal hizmet uzmanlarının görüşleri de dikkate alınmıştır. Tahliye, sevk veya değişik nedenlerle örneklem grubundan ulaşılamayan ya da ulaşılmasına rağmen anket için gönüllü olmayan bireylerin yerine, evrenden tesadüfi yöntemlerle seçilmiş kişilerle sayı tamamlanmıştır. Akabinde, Adalet Bakanlığı Ceza ve Tevkifevleri Genel Müdürlüğü tarafından iznin verildiği 04.05.2015-26.06.2015 tarihleri arasında izin alınan cezaevlerindeki psiko-sosyal servislerin de desteği ile uygulanmıştır. Konunun hassasiyeti sebebi ile anket, kurumdaki görevli psikolog veya sosyal çalışmacı gözetiminde gerçekleştirilmiştir. Anket içerisinde elde edilen veriler, SPSS paket programı aracılı̆̆ı ile değerlendirilmiştir. Verilerin analiz edilmesinde katılımcılardan alınan verilere ilişkin tanımlayıcı istatistikler olarak dağılımlar verilmiş ve yorumlanmıştır.

Çalışma sürecinde, elde edilen verilerin sayısal olarak ele alındığı ve açıklandığı nicel araştırma yöntemi benimsenmiştir. Araştırmanın modeli tarama modelidir. Tarama modeli, olgulara ilişkin bilgilerin tanımlanması ve betimlenmesini amaçlamaktadır(Karasan,1999). Bu araştırmada, cezaevlerindeki hükümlü ve tutukluların intihar eylemlerine ilişkin bilgilerin betimlenmesi yapılmaya çalışıldığından dolayı tarama modeli tercih edilmiştir. Çalışmanın örnekleme metodu, evren içerisinde eşit koşullara sahip bireylerin araştırmada yer aldığı örnekleme türü olan basit tesadüfi örneklemedir. Türkiye'de cezaevlerinde bulunan ve intihar girişiminde bulunmuş kişiler rastgele seçildiğinden ve eşit koşullara sahip örneklem içerisinden seçildiği için bu örnekleme türü seçilmiştir. Araştırma sonucu elde edilen bilgiler, araştırma alanı olan cezaevleri ve örneklem grubu ile sınırlı tutulmuştur.

Örneklem grubunda yer alan hükümlü ve tutukluların alkol ve madde bağımlılığına ilişkin tespitlerde ise kişilerin kendi beyanları, sağlık raporları ve kurumun psiko-sosyal servis görevlilerinin değerlendirmeleri esas alınmıştır. 
Çalışmada ilk bakışta bağımlılıkla ilgili görülebilecek bazı intihar girişimine benzer davranışlar göz ardı edilmiştir. Örneğin bazı insanların kendine zarar verme davranışını gerçekleştirirken, yaşamak ve ölmek arasında tam bir tercih yapamadıkları, yaşadıkları hayatı yaşamak istemeyip ama ölmeyi de göze alamadıkları durumlar söz konusu olabilmektedir. Cezaevlerinde de zaman zaman rastlanılan, ne doğrudan bir intihar davranışı ne de ikincil bir kazanç elde etme amaçlı manipülatif bir girişim olarak görülebilecek bu davranış, hükümlü ve tutuklular genellikle anti-depresan hapları yasadışı olarak biriktirip, aşırı doz halinde kullanmak şeklinde uygulamaktadırlar(Ivanoff\&Jang,1991:397). Bu nedenle sebep ve sonuç açısından benzerlik gösterse de, parasuicide adı verilen bu davranış araştırmamızda dikkate alınmamıştır.

Araştırma kapsamında cezaevlerinde küçük bir örneklem üzerinden, geriye dönük ve tanımlayıcı bir analizi yapılmaya çalışılmıştır. Kontrol grubu kullanılmayan bu araştırmada, sonuçlar kolayca genelleştirilmemeye ve dikkatli bir şekilde yorumlanmaya çalışılmıştır.

\section{BULGULAR}

Türkiye'de çeşitli bölge ve tiplerde, 18 ayrı ceza infaz kurumunda ve 102 hükümlü/tutuklu ile yapılan çalışma sonucu, aşağıdaki bulgulara ulaşılmıştır.

Tablo 1 : Katılımcıların Cinsiyetlerine İlișkin Bulgular

\begin{tabular}{|c|c|c|}
\hline Cinsiyet & S & $\%$ \\
\hline Erkek & 79 & 77,5 \\
\hline Kadın & 23 & 22,5 \\
\hline Toplam & 102 & 100,0 \\
\hline
\end{tabular}

Araştırmaya katılan bireylerin \%77,5'ini erkek mahpuslar oluşturuyorken, \%22,5'ini kadın mahpuslar oluşturmaktadır.

Araştırmaya katılanların yaş aralığı tablo 2'de verilmiştir.

Tablo 2: Katılımcıların Yaşlarına ilișkin Bulgular

\begin{tabular}{|c|c|c|}
\hline Yaş aralığı & $\mathrm{S}$ & $\%$ \\
\hline $18-20$ yaş aras1 & 2 & 2,0 \\
\hline $21-40$ yaş aras1 & 85 & 83,3 \\
\hline 40-64 yaş aras1 & 15 & 14,7 \\
\hline Toplam & 102 & 100,0 \\
\hline
\end{tabular}

Araştırmaya katılan bireylerin yaş ortalaması 32,5 iken, \%83,3 gibi önemli bir çoğunluğu 21-40 yaş aralığında bulunmaktadır. Örneklem grubundaki en düşük yaş 18 olup, en yüksek yaş ise 63'tür.

Araştırmaya katılanları medeni durumlarına ilişkin veriler tablo 3 ’te verilmiştir.

Tablo 3: Katılımcıların Medeni Durumlarına İlişkin Bulgular

\begin{tabular}{|c|c|c|}
\hline Medeni Durum & $\mathrm{S}$ & $\%$ \\
\hline Evli & 38 & 37,3 \\
\hline Bekar & 35 & 34,3 \\
\hline Boşanmış & 23 & 22,5 \\
\hline Eşi vefat etmiş & 6 & 5,6 \\
\hline Toplam & 102 & 100,0 \\
\hline
\end{tabular}

Yapılan çalışmaya katılan bireyler \%37,3'ü evli iken, \% 34,3'lük bir kısım bekâr olup; boşanmış olanların oranı \%22,5'tir. Eşi vefat etmiş olan mahpusların oranı ise \%5.6'dır.

Araştırmaya katılanların cezaevi öncesi dönemde alkol ya da madde kullanımına dair öyküsü bulunup bulunmadığına dair veriler tablo 4'de verilmiştir.

Tablo 4: Katılımcıların Cezaevi Öncesi Dönemde, Alkol ya da Madde Kullanımına Dair Öyküsü Bulunma Durumuna İlişkin Bulgular

\begin{tabular}{|c|c|c|}
\hline & S & \% \\
\hline Hayır & 30 & 29,4 \\
\hline Alkol & 40 & 39,2 \\
\hline Uyuşturucu & 16 & 15,7 \\
\hline Her İkisi de & 13 & 12,7 \\
\hline Diğer & 3 & 2,9 \\
\hline Toplam & 102 & 100,0 \\
\hline
\end{tabular}


Araştırmaya katılan bireylerin \%39,2'si alkol bağımlısı olduğunu ifade etmekteyken, \%15,7'sinin madde bağımlısı olduğu ortaya çıkmıştır. Hem alkol hem madde bağımlısı olan mahpusların oranı ise \%12,7'dir. Toplamda (\%39,2+\%15,7+\%12,7), \%67,6 oranında bir çoğunluğun geçmişinde alkol ya da madde kullandığı bir dönemin olduğu görülmektedir.

Katılımcılardan, kuruma girdikten sonra girişimde bulunduğu döneme kadar geçen süreye ilişkin bulgular tablo 5'de verilmiştir.

Tablo 5: Katılımcıların Kuruma Girdikten Sonra İntihar Girişiminde Bulunduğu Döneme Kadar Geçen Süreye İlişkin Bulgular

\begin{tabular}{|c|c|c|}
\hline & $\mathbf{S}$ & $\boldsymbol{\%}$ \\
\hline & 1 & 1,0 \\
\hline İlk Gün & 5 & 4,9 \\
\hline 1 Hafta İçinde & 15 & 14,7 \\
\hline İki Hafta İçinde & 8 & 7,8 \\
\hline İlk Ay İçinde & 23 & 22,5 \\
\hline 1-6 Ay Aras1 & 8 & 7,8 \\
\hline 1-2 Y1l Aras1 & 20 & 19,6 \\
\hline 2-4 Y1l Aras1 & 12 & 11,8 \\
\hline 4-8 Y1l Aras1 & 5 & 4,9 \\
\hline 8-10 Y1l Aras1 & 3 & 3,0 \\
\hline 10 Y1l ve Üzeri & 2 & 2,0 \\
\hline Yanitlamayan & 102 & 100,0 \\
\hline Toplam & & \\
\hline
\end{tabular}

Örneklem grubunda yer alan hükümlü ve tutukluların \%51'inin ilk 6 ay içerisinde intihar girişimde bulunduğu anlaşılmaktadır. Bu mahpusların, yığınsal olarak bakıldığında, özellikle \%28,4'ünün ilk 1 ay içerisinde, \%20,6'sının ilk iki hafta içinde girişimde bulunduğu görülmektedir. Hükümlü ve tutukluların kuruma girişini takip eden 8 yıldan sonraki dönemde intihar girişiminde bulunanların oranlarının belirgin biçimde azaldığı gözlemlenmiştir.

Katılımcıların intihar düşüncesini girişim aşamasına taşınmasındaki sebeplerine ilişkin bulgular tablo 6'da verilmiştir.

Tablo 6: Katılımcıların İntihar Düşüncesini Girişim Aşamasına Taşınmasındaki Sebeplerine İlişkin Bulgular

\begin{tabular}{|c|c|c|}
\hline & S & \% \\
\hline Aile İçi Sorunlar & 39 & 38,2 \\
\hline Ekonomik Sorunlar & 3 & 2,9 \\
\hline Fiziksel Hastalı & 1 & 1 \\
\hline Yakınlarından Birini Kaybetme & 5 & 4,9 \\
\hline Madde ve alkol yoksunluğunu & 4 & 3,9 \\
\hline Kurum Koşulları & 11 & 10,8 \\
\hline Disiplin Cezası & 7 & 6,9 \\
\hline Cezanın Onanması Ya Da Ceza Süresi & 8 & 1,8 \\
\hline Psikolojik Sorunlar & 20 & 2,9 \\
\hline Suç ile ilgili & 3 & 1 \\
\hline Diğer & 1 & 100,0 \\
\hline Toplam & 102 & \\
\hline
\end{tabular}

Araştırmaya katılan bireylere intihar girişiminde bulunma sebepleri sorulduğunda, \%38,2 oranı "aile içi sorunlar" olduğunu, \% 19,6'sı ise "Psikolojik sorunlar" nedeni ile intihar girişimde bulunduklarını ifade etmişlerdir. İntihar girişimlerini "Kurum koşulları" ile ilişkilendirenlerin oranı \%10,8'dir. "Cezanın onanması veya ceza süresinin uzun olduğu” düşüncesinin etkisi ile girişimde bulunanların oranı \%7,8 iken, kurumda aldığı "disiplin cezasına” öfkelenip girişimde bulunan hükümlü ve tutukluların oranı ise \%6,9'dur. "Yakınlarından birini kaybetmenin etkisi”" ile girişimde bulunan mahpusların oranı \%4,9'dur. İntihar girişiminde "madde ve alkol yoksunluğunun" etkili olduğu kişilerin oranı \% 3,9 oranındadır. İşlediği suç nedeniyle girişimde bulunan mahpusların ve ekonomik nedenlerle intihar girişiminde bulunanların oranı ise \%2,9'dur. İntihar girişimine yol açan nedenlerin arasında en az rastlanılan, \%1 oranında olan fiziksel hastalıklarını gerekçe gösterenlerdir.

\section{TARTIŞMA}

Araştırmamızda intihar girişiminde bulunan hükümlü ve tutukluların sosyo-demografik özellikler açısından cinsiyet, yaş ve medeni durumu göz önünde bulundurularak bazı bulgular elde edilmiştir. Bu bulgulardan cinsiyet ile ilgili olanını, dünya cezaevleri ile karşılaştırdığımızda erkeklerin daha fazla intihar davranışında bulunduğuna dair sonuçlarla benzerlik göstermektedir. Dünya cezaevlerinde intihar davranışının cinsiyet ve cinsiyet rolleri bağlamında ele alan çalışmalarda, birçok ülkede erkek intihar oranlarının, kadın intihar oranlarından birkaç kat fazla olduğu görülmektedir (Beautrais,2006:154). Yine batıdaki cezaevlerindeki intihar davranışları cinsiyete göre değerlendirildiğinde, White ve Schimmel (1995: 51), cezaevi 
nüfusunun \%7'sinin kadınlardan oluşmasına rağmen, bütün federal cezaevlerinde intiharların tamamının erkekler tarafından gerçekleştirildiğini belirtmektedir. Medeni durum açısından intihar girişiminde bulunan bekar, boşanmış ve eşi vefat etmiş olanların sayısı, evlilere oranla daha fazla olarak ortaya çıkan bulgularımızla, dünyada yapılmış farklı araştırmalarda da evlilerin daha az intihar davranışında bulunduğuna dair sonuçlar yine benzerlik göstermektedir. Bu bağlamda yurtdışında yapılan çalışmalarda, intihar oranının genellikle evlenmemiş mahpuslarda daha yüksek olduğunu gösteren birçok araştırma mevcuttur (Hayes,1989:18; Tartaro \& Lester., 2010: 220; Saavedra \& López,2015:228). Örneğin Hayes ve Rowan'ın (1988:6) çalışmasına göre cezaevi nüfusunun \%52'si bekâr, \%4'ü ayrılmış, \%14'ü ise boşanmıştır.). İntihar davranışı ve yaş arasındaki ilişki açısından elde ettiğimiz bulgularda ise, genç hükümlü ve tutuklularda bu eğilimin daha fazla olduğunu görülmektedir. Benzer bir şekilde yurtdışı araştırmalarında da cezaevinde intihar davranışı ve kendine zarar verme gibi durumlara tanıklık eden genç erkek mahpuslarda daha yüksek düzeylerde tespit edildiği araştırmalar bulunmaktadır(Hales vd.,2014:12).

Çalışmamızın esasını teşkil eden, alkol ve madde kullanımından kaynaklı intihar davranışları boyutu ile ilgili olarak yurtdışındaki araştırmalara baktığımızda ise, konunun iki ayrı açıdan ele alındığını görmekteyiz. İlki hükümlü ve tutukluların cezaevine geldikleri ilk 24 saat veya ilk 3 gün içerisinde gerçekleştirdikleri intihar davranışları ile madde ve alkol bağımlılığın (sarhoşluk hali veya maddenin etkisi altında olma gibi) etkisi arasındaki ilişkiye yönelik çalışmalardır (Hayes, 1995; Fazel vd., 2008: 1729; Hayes, 2010). Örneğin Hayes yaptığı bir araştırmada (1995), ilk 24 saat içinde intihar teşebbüsünde bulunan hükümlü ve tutukluların \%60'ının bu davranışı alkolün, uyuşturucunun ya da her ikisinin etkisi altında gerçekleştirdiğine dair bulgulardan bahsetmiştir (Hayes, 1995). Diğeri ise, konuyu bu araştırmanında ele aldığı gibi, bağımlı bir bireyin hüküm alması ya da tutuklanması sonrasında cezaevine girmesi ile birlikte, madde ve alkol kullanamadığı için yaşadığı yoksunluk semptomlarına bağlı olarak intihar davranışına yönelmesi açısından ele alan araştırmalardır(Liebling, 1999:288; Wright,1991:308). Araştırmamızda, örneklem grubunda yer alan mahpusların kendini madde ve alkol kullanımı açısından birine ya da ikisine birden bağımlı görenlerin oranı 2/3 gibi yüksek bir rakamdır. Bu bağımlılık tanımlamasında kişilerin, cezaevine girmeden önceki dönemlerde, alkol ve/veya uyuşturucu kullanmamanın psikolojilerinde meydana getirdiği bir takım olumsuz davranışlar üzerinden tanımlanmıştır. Kendini bu grupta gören mahpusların intihar davranışına yönelimindeki rakamların yüksekliği, bize bağımlılık durumunun intihar girişimini artırabilecek önemli risk faktörleri arasında yer aldığını göstermektedir. Yine araştırmamız, madde ve alkol bağımlılığından kaynaklı yoksunluk semptomları var olan hükümlü ve tutukluların, intihar davranışları için az bir oranda da olsa risk faktörü taşıdığını ortaya koymaktadır. Bu risk faktörünün azalması ya da artması kurumun konuya yaklaşımına bağlı olarak değişkenlik gösterebilmektedir.

Bazı kişiler yaşadığı acılarla baş etme yöntemlerinden biri olarak intihar davranışına (Apaydın vd.,2016), bazı kişiler ise madde ve alkol kullanımına yönelebilmektedir (Erbay vd.,2016). Yine bu iki olgu arasında karşılıklı bir ilişki kuran ve neden sonuç yönü ile hangisinin sebep, hangisinin sonuç olduğunun net olmadığını söyleyen bir görüş de bulunmaktadır(Felts vd.,1992:871). Her iki araştırmanın ortak noktası ise, bağımlı olan kişilerin intihar yöneliminin, bağımlı olmayan kişilere göre daha yüksek oranda olduğunu göstermesidir. Araştırmamızda mahpusların yaklaşı \% 4'ü kendi ifadeleri ile yoksunluğun doğrudan intihar davranışına sebep olduğunu ifade etmektedirler. Fazel ve arkadaşları da (2008), cezaevlerinde yoksunluğun intihar davranışına yol açan önemli risk faktörlerinden biri olarak ifade etmektedir(Fazel vd., 2008:1728). Ayrıca Dünya Sağlık Örgütünün yayınladığı bir raporda, madde ve alkol bağımlılığı olan kişilerin hüküm alma ya da tutuklanma sonucu ceza infaz kurumuna girmesinin, kişileri aynı zamanda madde ve alkolden uzak kalma anlamına geldiği için, mahpusların kendi sorunları ile yüzleşme ve problemleri ile başa çıkma yeteneğinin kaybı yanında, diğer yoksunluk kaynaklı olarak yaşadığı yoğun stres nedeni ile de, bireyin intihar davranışına yönelmesine sebep olabildiği belirtilmektedir(W.H.O;1992).

Cezaevinde bağımlıların tedavisine yönelik olarak farklı çalışmalar yapılmaktadır. Zaten dışarıda bulunan bir bağımlının tedavi süreci ile cezaevinde bulunan bir bağımlının tedavi süreci dönemler itibari ile birbirine benzetilebilir. Özellikle her bağımlının ya da bağımlılığın tedavisi kendi içinde değişkenlik göstermekle birlikte, iyileşme sürecindeki bazı dönemlerin genelleştirilebileceğinden bahsedilebilir. Bu dönemler dişarıdaki bağımlılar için 1.dönem: Yoksunluk Dönemi (0-1 ay): 2 . Dönem: Coşku dönemi (1-3 ay), 3.Dönem: Sıkılma dönemi (3-6 ay), 4. Dönem: Yeni hayat dönemi (6 ay ve sonrası), olarak 4 ayrı dönem olarak ele alınabilir. Bu dönemlerden, ruhsal ve bedensel huzursuzluklar ile rahatsızlıkların yoğun olduğu, bağımlı kişinin ani duygusal geçişleri yaşayabildiği yoksunluk dönemi bağımlılar için en zor dönem olarak ifade edilmektedir (Dilbaz;2013). Cezaevi nüfusunda bağımlıların yaygınlığg göz önüne alındığında, özellikle hapsedilmenin başlangıç döneminde, yoksunluktan kaynaklı yaşanabilecek problemlerin önlenmesinde dikkat gerektirmektedir. Bu süreçte madde bağımlısı hükümlü ve tutukluların kuruma girişlerinden itibaren yoksunluk hislerini azaltmak için metadon tedavisi ile cezaevi şartlarına geçiş yapmasını öneren çalışmalar mevcut olduğu gibi (Chandler vd.,2009:186), halen ülkemizde uygulanmasa da, madde kullanımını bırakamayan kullanıcılara yönelik zarar azaltma programlarını devreye sokulmasını öneren farklı çalışmalar mevcuttur (Sander vd.,2019:107). Yapılan birçok çalışmada da, mahpusların cezaevine girdikten sonra ya da hüküm giydikten kısa bir süre sonra, özellikle de yoğun kişisel stres yaşadıkları dönemde, intihar davranışlarına olan eğilimlerinin arttığına değinilmektedir (Liebling, 1999; Blaauw vd., 2002:12; Stoliker,2018: 594). Genel itibari ile ise cezaevi intihar önleme programlarının önemli bir kısmı da, bağımlı olduğu düşünülen hükümlü ve tutukluların özellikle ilk 24 saat ve sonraki 3 günlük periyotlarda daha dikkatli izlenmesine yönelik öneriler sunmaktadır (Hayes,1995, Bonner, 1992,. White \& Schimmel,1995). Araştırmamızda Tablo 5'de yer alan veriler üzerinden bu dönemleri değerlendirdiğimizde, yoksunluk dönemini içine alan ilk 1 aylık sürenin, cezaevlerinde de bağımlılar için en fazla dikkat edilmesi gereken dönem olduğu düşünmekteyiz. Zaten uygun programların uygulanması durumunda cezaevlerinde madde ve alkol bağımlılarına yönelik olarak gerçekleştirilen tedavilerin yararlı etkilerini tutarlı bir şekilde raporlarında yansıtan çeşitli araştırmalar bulunmaktadır (Inciardi vd.,1997:275; Pearson \& Lipton,1999:394). Bunun dışında uluslararası araştırmalarda da dikkat çeken (Fazel vd.,2017:950;. Frottier vd. 2000: 416) ve araştırmamızda da benzer bulgulara ulaştığımız ceza infaz kurumunda belli bir dönem sonrası gözlemlenen intihar davranışlarındaki oransal azalmaların 
sebebinin, tedaviden bağımsız olarak kurum şartlarına uyum sağlamaları ile ilgili olduğunu düşündürtmektedir. Madde ve alkol bağımlıları açısından konuyu değerlendirildiğimizde ise bu durum, yoksunluktan kaynaklı sorunların, belli bir zaman eşiğinden sonra zamanla azalabildiği şeklinde bir değerlendirmeyi akla getirmektedir.

\section{SONUÇ}

Sosyal şartlara da bağlı olarak daha fazla sayıda alkol ve madde bağımlısı hükümlü ve tutuklu cezaevlerine giriş yapmaktadır. Bu kişilerin sadece intihar davranışlarına neden olması ile ilgili olarak değil, cezaevi disiplinini bozan ya da rehabilite olma sürecini sıkıntıya sokarak cezaevi koşullarına uyumu zorlaştırması nedeni ile de bağımlılıklarının tedavi edilmesi gerekmektedir. Gerek intihar davranışlarının azaltılması, gerekse cezaevlerinde daha başka sorunlara yol açabileceği nedeni ile, bağımlılık ve intihar davranışları ile ilgili aşağıdaki önerilerin sunulması uygun görülmüştür.

-Cezaevlerinde intihar girişimi olması durumunda acil müdahale prosedürleri geliştirilmeli, müdahale edecek personel intihar yöntemine göre değişen müdahale programı için eğitilmelidir.

-İntihar teşebbüsünün tekrarlamaması için, derhal girişimde bulunan hükümlü veya tutuklunun sorunun teşhisine yönelik çalışmalara başlanmalıdır.

-Hükümlü ve tutukluların kuruma ilk kabullerinde risk analizini içeren formun, üniversiteden akademisyenlerinde yer aldığ 1 bir komisyon tarafından sık sık güncellenmeli, özellikle madde ve alkol bağımlılığı olan kişilere, cezaevine girdikleri ilk saatlerden ve günden başlayarak, risk faktörlerini taşıyıp taşımadıklarına dair testler, daha hassas bir şekilde uygulanmalıdır.

-Bu kapsamda, daha önce intihar girişimi öyküsü olup olmadığı, depresyon ya da diğer faktörlerle ilişkisi üzerinden konuya yaklaşıp risk değerlendirmesi yüksek çıkan hükümlü ve tutukluların, izlenmesine dair prosedürler dahilinde, intihar davranışını kolaylaştıracak fiziki unsurların bulunmadığı kısımlarda barınmaları sağlanmalıdır. Hükümlü ve tutukluların ilk geldikleri süreçte izleme için kalacakları ortamlarda ip, kesici alet, kimyasal ürünler ya da ası amaçlı kullanabileceği malzemeler ve ası noktası olarak yararlanılabileceği noktaların bulunmaması hususu dikkatle gözden geçirilmelidir.

-Bütün bu süreçte, intihar davranışlarına yönelik önleyici ve sonrasında rehabilite edici çalışmalar için personele gerekli eğitimler ile, intihar girişimi öyküsü ya da riski olan hükümlü ve tutuklulara yönelik stres ve öfke gibi kendine zarar verme ve intihar davranışına sebebiyet verecek duygularla baş etmek için temel programlar bireysel veya grup terapileri şeklinde verilmelidir.

-Bağımlılık durumu olan veya geçmişinde alkol ve madde öyküsü bulunan hükümlü ve tutukluların takibi daha yakından yapılmalıdır. Bu yapıdaki kişilerin, yoksunluk nedeni ile yaşayabileceği problemler her biri için ayrı ayrı değerlendirilmelidir. İntihar girişiminde bulunanlarla, farklı niyetlerle kendine zarar verme davranışında bulunan kişiler için farklı stratejiler geliştirilmelidir.

-Bağımlılık öyküsü olan hükümlü ve tutuklular ceza infaz kurumuna girmeden önce tedavi görmüşlerse, daha önceki sürecini takip eden AMATEM gibi kuruluşlarla işbirliği yapılmalı ve intihar davranışı yordanmaya çalışırken, hem geçmiş hem de mevcut veriler birlikte değerlendirmeye çalışılmalıdır.

\section{KAYNAKÇA}

Apaydın, H., Özdemir, Ş. Ve Zaroğlu Ünal, A. (2016). İntihar Girişiminde Bulunan Bireylerde Bazı Değişkenlerle İntihar Girişimi İlişkisi. Amasya Üniversitesi İlahiyat Fakültesi Dergisi,6,7-44.

Beautrais, A. L. (2006). Women and suicidal behavior. Crisis, 27(4), 153-156.

Blaauw, E., Arensman, E., Kraaij, V., Winkel, Ve Bout, R. (2002). Traumatic Life Events And Suicide Risk Among Jail İnmates: The İnfluence Of Types Of Events, Time Period And Significant Others. J. Trauma Stress 15, 9-16.

Bonner, R.L. (1992). Suicide Prevention In Correctional Facilities. In L. Vandecreek, S. Knapp, \& T. Jackson (Eds), Innovations İn Clinical Practice: A Sourcebook (Volume 11). Sarasota, Fl: Professional Resource Exchange.

Ceza ve Tevkifevleri Genel Müdürlüğü (2014). Ceza İnfaz Kurumlarında Intihar Olaylarl Değerlendirme Raporu,Adalet Bakanlığı Ceza ve Tevkifevleri Genel Müdürlüğü Bilişim ve Sağlık İşlerinden Sorumlu Daire Başkanlığ Araştırma ve İstatistik, Ankara.

Chandler Rk, Fletcher Bw, Volkow Nd. (2009) Treating Drug Abuse And Addiction İn The Criminal Justice System: Improving Public Health And Safety. Jama.;301(2):183-190.

Clements-Nolle, K., Wolden, M., Bargmann-Losche, J. (2009). "Childhood Trauma And Risk For Past And Future Suicide Attempts Among Women İn Prison” Women's Health Issues, 19, 185-192.

Dear, G. (2006). Preventing Suicide And Other Self-Harm In Prison, Palgrave Macmillan. Houndmills, Uk.

Dilbaz, N. (2013). Madde Kullanım Riski Ve Madde Bağımlılı̆̆ından Korunma. Ankara: T.C. Aile Ve Sosyal Politikalar Bakanlığı Aile Eğitim Programı

Duthe, G., Harzad, A., Kensey, A. (2014). Trends And Risk Factors For Prisoner Suicidein France. Population, English Edition, 69(4), 463-494. 
Dye, M. H. Ve Aday, R. H. (2013). I Just Wanted To Die”: Preprison And Current 181 Suicide Ideation Among Women Serving Life Sentences. Criminal Justice And Behavior, 40(X), 832-849.

Erbay, E., Oğuz, N., Yıldırım, B. Ve Fırat, E. (2016). Alkol Ve Madde Bağımlılığg Olan Bireylerin Başa Çıkma Tutumları. Türkiye Sosyal Araştırmalar Dergisi, 3, 597-609.

Fazel, S., Cartwright, J.,Norman-Nott, A. (2008). “Suicide İn Prisoners: Asystematic Review Of Risk Factors”. Journal Of Clinical Psychiatry, 69, 1721-1731.

Fazel, S., Grann, M., Kling, B., Hawton, K. (2011). Prison Suicide İn 12 Countries: Anecological Study Of 861 Suicides During 2003-2007 . Social Psychiatry And Psychiatric Epidemiology, 46(3), 191-195.

Fazel, S, Yoon I.A. ve Hayes A.J. (2017). Substance Use Disorders İn Prisoners: An Updated Systematic Review And MetaRegression Analysis İn Recently İncarcerated. Men And Women Addiction, 112 (10) , Pp. 182-198.

Fazel, S., Ramesh, T. Ve Hawton, K. (2017). Suicide İn Prisons: An İnternational Study Of Prevalence And Contributory Factors. The Lancet. Psychiatry, 4(12), 946-952.

Felts Wm, Chenier T, Barnes R. (1992). Drug Use And Suicide İdeation And Behavior Among North Carolina Public School Students. Public Health.;82:870-872.

Frottier, P., Ritter, K., Frühwald, S., König, F., Ve Bauer, P. (2000). P02.346 Correlation Between Suicide Risk, Time Spent İn Prison And Vulnerability Profile Of People İn Confinement. European Psychiatry, 15(S2), 415-416.

Fruehwald, S., Frottier, P., Eher, R., Gutierrez, K., Ritter, K. (2000). “Prison Suicides İn Austria, 1975-1997”. Suicide-LifeThreating Behavior ,(4),360-369

Goss Jr, Peterson K, Smith Lw, Kalb K, Brodey Bb (2002). Characteristics Of Suicide Attempts İn A Large Urban Jail System With An Established Suicide Prevention Program. Psychiatric Services. ;55:574-579

Grossmann, M. G. (1992). “Two Perspectives On Aboriginal Female Suicides İn Custody: Special İssue: Aboriginal Criminal Justice İn Canada”. Canadian Journal Of Criminology, 34, 403-415.

Hayes, L. \& Rowan, J. (1988). National Study ofJail Suicides: Seven Years Later. National Center on Institutions And Alternatives, Alexandria, Virginia.

Hayes, L. M. (1989). National Study Of Jail Suicides: Seven Years Later. Psychiatric Quarterly, 60(1), 7-29.

Hayes, L. M. (1995). "Prison Suicide: An Overview And Guide To Prevention”. The Prison Journal, 75, 31-456.

Hayes, L., National Institute Of Corrections. (2010). National Study Of Jail Suicide: 20 Years Later (024308). U.S. Department Of Justice

Haycock, J. (1989). “Manipulation And Suicide Attempts İn Jails And Prisons”. Psychiatric Quarterly, 60(1), 85-98.

Inciardi Ja, Martin Ss, Butzin Ca, Hooper Rm, Harrison Ld. (1997). An Effective Model Of Prison-Based Treatment For Drugİnvolved Offenders. J Drug Issues;27(2):261-278.

Ivanoff, A., \& Jang, S. J. (1991). The role of hopelessness and social desirability in predicting suicidal behavior: A study of prison inmates. Journal of Consulting and Clinical Psychology, 59(3), 394-399

Karasar, N. (1999) Bilimsel Araştırma Yöntemi, Ankara: Nobel Yayınevi.

Konrad N, Daigle MS, Daniel AE, Dear GE, Frottier P, Hayes LM, Kerkhof A, Liebling A, Sarchiapone M: Preventing suicide in prisons, part I: recommendations from the International Association for Suicide Prevention Task Force on Suicide in Prisons. Crisis 2007; 28:113-121

Krames, L. \& Flett, G. (2005). Jail / Holding Cell Design. Proposals For Modification And Design Changes. Cprc, Tr-03-2000, Ontario,Canada.

Liebling, A. (1999). Prison Suicide And Prisoner Coping. Crime And Justice, 26, 283-359

Marzano, L., Hawton, K., Rivlin, A., Fazel, S. (2011). Psychosocial İnfluences On Prisonersuicide: A Case-Control Study Of Near-Lethal Self-Harm İn Women Prisoners. Social Science And Medicine, 72, 874-883.

Matschnig, T.\& Fruhwald, S., Frottier, P. (2006). Suicide Behind Bars - An İnternational Review. Psychiatrische Praxis, 33(1), 6-13.

Ögel, K., Karalı, A., Tamar, D. Ve Çakmak, D. (1998). Alkol ve Madde El Kitabı. İstanbul: AMATEM Bakırköy Ruh Ve Sinir Hastalıkları Hastanesi.

Palmer, E.J. \& Connelly, R. (2005). Depression, Hopelessness And Suicide İdeation Among Vulnerable Prisoners, Criminal Behaviour And Mental Health, Sayı: 3, 164-170.

Saavedra J \& López M. (2015), Risk of suicide in male prison inmates. Rev Psiquiatry Salud Ment.;8(4), $224-231$. 
Sander G, Shirley-Beavan S, Stone K.( 2019). The Global State Of Harm Reduction İn Prisons. J Correct Health Care.;25(2):105-120.

Stoliker, B. E. (2018). Attempted Suicide: A Multilevel Examination Of Inmate Characteristics And Prison Context. Criminal Justice And Behavior, 45(5), 589-611.

Stuart, H. (2003). Suicide Behind Bars. Current Opinion In Psychiatry, 16(5), 559-564.

Sykes, G. (1958). The Society Of Captives, Princeton University Press, Princeton.

TC Başbakanlık Türkiye İstatistik Kurumu (2015). Türkiye İstatistiği Yıllı̆̆l, Ankara. Mevzuatı Geliştirme ve Yayın Genel Müdürlüğü (2006), https://www.mevzuat.gov.tr/mevzuat?MevzuatNo=8344\&MevzuatTur=7\&MevzuatTertip=5, $(17 / 07 / 2020)$

Tartaro,C., Lester, D. (2010). Suicide and Self Harm in Prisons and Jails, Lexington Books, Lanham, MD.

Towl, G., Snow, L., Mchugh, M. (2001). Suicide In Prisons, Blackwell, Oxford.

Pearson, F.S. and Lipton, DS (1999). A Meta-Analytic Review of the Effectiveness of Corrections-Based Treatment for Drug Abuse. The Prison Journal 79(4):384-410

White,T. W., Schimmel, D. (1995). “Suicide Prevention İn Federal Prisons: A Successful Five-Step Program”. Prison Suicide: An Overview And Guide To Prevention. (Ed. L. M. Hayes) , 48-59. U.S. Department Of Justice: National Institute Of Corrections.

World Health Organization (1992). Drug Users In Prison: Managing Their Health Problems (Who Regional Publications, European Series, No. 27). Copenhagen, Denmark: World Health Organization.

Wright, T. A. (1991). Coping, Behavior, And Adaptation İn Prison İnmates. Journal Of Criminal Justice, 19(3), 307-308. 